\title{
Basal Cell Carcinoma of Breast Metastasis to Axillary Lymph Node: A Case Report and Comprehensive Literature Review
}

\author{
Journal of Medical Clinical Case Reports
}

Case Report

\author{
Rabia Niaz $^{1^{*}}$, Rufina Soomro ${ }^{2}$ and Javaria Parwez ${ }^{3}$ \\ ${ }^{1}$ Fellow Breast Surgery, Liaquat National Hospital and \\ Medical College, Karachi- Pakistan
}

${ }^{2}$ Prof. of Surgery, Liaquat National Hospital and Medical College, Karachi- Pakistan

${ }^{3}$ Resident Histopathology, Liaquat National Hospital and Medical College, Karachi- Pakistan

\author{
*Corresponding Author \\ Prof. Rufina Soomro \\ Professor of Surgery \\ Liaquat National Hospital and Medical College \\ Karachi \\ Pakistan
}

Submitted : 5 Dec 2021 ; Published : 21 Dec 2021

\begin{abstract}
Basal cell carcinoma (BCC) metastasis incidence is rare and occurs in advanced, neglected, recurrent tumors or tumors with high risk histopathologic features like perineural invasion. The mainstay of management remains surgical excision with clear margins wherever possible followed by radiotherapy. We are presenting a case of metastatic BCC of an uncommon site i.e., anterior shoulder with metastasis to axillary lymph nodes and to review literature regarding the current standard of management.
\end{abstract}

Keywords: Metastatic basal cell carcinoma, regional node metastasis, high risk BCC, Radiotherapy.

\section{Introduction}

Basal cell carcinoma (BCC) is the most frequent cutaneous malignancy of sun exposed skin among the fair population over 50 years (Peris et al., 2019). It is a slow growing tumor with local invasion and metastasis rarely (Basset-Seguin \& Herms, 2020). The annual incidence is reported to be $0.0028-0.055 \%$ however; the risk of under reporting should be considered (Gellatly et al., 2020). European consensus based guidelines have classified BCC into easy-to-treat and difficult-to-treat groups that includes the locally advanced and metastatic disease (Peris et al., 2019). The metastasis is seen in large, recurrent tumors or incompletely excised tumors (Furlan et al., 2021). The reported cases with metastasis most commonly originate from the primary head and neck region due to close relation with vital structures i.e., brains and eyes (Mohan \& Chang, 2014). We are here presenting a case of a patient with regional nodal metastasis of primary BCC of an unusual site which was missed at the time of initial surgery and later presented as an axillary lump and to give a comprehensive literature review regarding basal cell carcinoma and recent advances in management.

\section{Case report}

A 67 years old female known hypertensive presented with a lump in left axilla noticed two months ago. The patient had a history of ulcer over left anterior shoulder for more than a year that was excised and primary closure was performed three months ago in a local clinic (Figure1). The tumor histopathology revealed basal cell carcinoma of size $2.5 \times 1.5 \times 1.4 \mathrm{~cm}$ with focal skin ulceration. The depth of invasion was $1.4 \mathrm{~cm}$; the tumor was $0.4 \mathrm{~cm}$ away from the closest peripheral margin and $0.3 \mathrm{~cm}$ away from the deepest margin. Positron emission tomography
(PET) scan was done after the surgery that reported a single hyper metabolic left axillary lymph node measuring $21 \times 15 \mathrm{~mm}$ with SUV max 7.3 and no residual metabolic activity at the primary site of tumor and no distant metastasis. The complete physical examination did not show any lump in breast but a lump was present in the left axilla measuring $3 \times 4 \mathrm{~cm}$ that was partly fixed. Breast imaging showed benign findings (BIRAD II). Core biopsy was performed for the axillary node and histopathology was poorly differentiated carcinoma, BerEP4, CK7 and CK AE1/AE3 was positive on immune-histochemical staining and thus the diagnosis of metastatic basal cell carcinoma. Patient underwent axillary clearance and it was reported as metastatic carcinoma of size $6 \times 4.5 \times 2 \mathrm{~cm}$ with focal lymphovascular invasion, rest of lymph nodes were negative for malignancy. Case was discussed in a multidisciplinary board meeting including medical and radiation oncologist and planned for local radiotherapy due to high risk characteristics of the tumor. Patient underwent radiation therapy of 50Gy in 20 fractions (2.5Gy per fraction) to the left anterior shoulder and axilla. The patient is under close follow up.

\section{Discussion}

Basal cell carcinoma is the commonest malignancy with a lifetime risk of 30\% (Lernia et al., 2013). Locally advanced $\mathrm{BCC}$ are $1-10 \%$ of all BCC however, metastasis is even more rare (Mohan \& Chang, 2014). 170 cases of histology proven metastatic BCC have been reported in literature from 1981 till 2011(McCusker et al., 2014). However, some papers report up to 300 cases (Laga et al., 2019). The common sites are sun exposed or UV light exposed areas like head and neck (80- 
$85 \%$ ) and less than $2 \%$ occur at the abdomen, genital areas, upper chest and shoulder are more rare sites. Other risk factors include immunosuppression, organ transplant recipients, genetic diseases (e.g., Gorlin-goltz syndrome) (Didona et al., 2018).

$\mathrm{BCC}$ has indolent growth from a tiny papule to ulceration over years and can sometimes cause local invasion and destruction but metastasize rarely. European consensus classifies these tumors as 'easy to treat' which can be treated effectively by complete excision. The 'difficult to treat' group includes the simple BCC that pose difficulty in surgical excision due to location, locally advanced BCC and metastatic BCC (Peris et al., 2019). The risk factors for metastatic BCC include large tumor size, depth of invasion beyond subcutaneous fat, located at head and neck, aggressive histologic subtypes (baso-squamous, sclerosing, infiltrative and micronodular differentiation), immunosuppression, prior site of radiotherapy, perineural invasion( listed by American Joint Committee on Cancer) and local recurrence of primary tumor (Gellatly et al., 2020; Branson et al., 2020). Our patient had a long standing history, had advanced to ulcer formation, was near to the axillary lymph node draining region and histopathology showed poorly differentiated carcinoma with lymphovascular invasion which could be the risk factors of the development of metastasis.

Epithelial malignancy metastasis is by the epithelial mesenchymal transition pathway but there are limited studies in this regard (Mochel et al., 2021). BCC initial spread is via the lymphatic route to the regional lymph nodes and rarely distant metastasis via hematogenous route (Gellatly et al., 2020). The common reported sites for hematogenous spread in literature are lungs and bones. However, high risk BCC early spread to the regional lymph nodes via lymphatic route as seen in the case reported regional nodal metastasis. This signifies the importance of local and regional nodes clinical examination and request appropriate radiologic evaluation in all cases of BCC to avoid any missed metastasis esp. in advanced, recurrent and high risk patients (Gellatly et al., 2020).

Diagnosis of BCC is by excision and histopathology which also identifies the high risk markers including the histologic type such as infiltration, basosquamous, morphed form, sclerosing or micronodular, squamous cell differentiation, perineural and lymphovascular invasion (Laga et al., 2019). Routine radiologic investigations are not performed unless guided by the high risk clinical and histopathological features and should be advised judiciously and PET scan has shown to have utility in aggressive BCC only (West et al., 2020). Sentinel lymph node biopsy application for basal cell carcinoma to identify regional nodal metastasis is still controversial due to the rarity of metastasis of basal cell carcinoma. Further studies should be carried out to identify the group of BCC for whom the sentinel lymph node biopsy might be of help (Jankovic et al., 2011).

Surgical excision with a safety margin $4 \mathrm{~mm}$ for a low risk tumor size less than $2 \mathrm{~cm}$ as recommended by the NCCN guidelines is the standard surgical treatment. Mohs micrographic surgical excision is standard treatment option for high risk basal cell carcinoma and has shown low recurrence rates compared to standard surgical excision over a 10 year follow up in a randomized controlled trial (van Loo et al., 2014). However, complete excision of the tumor with an intraoperative frozen section of circumferential and deep margin is an acceptable alternative for high risk BCC (Mosterd et al., 2008). Although no guidelines are available, surgery is treatment of choice for all resectable tumors i.e., nodal dissections and cases have been reported where cervical lymph node dissection and pulmonary metastasectomy have been performed (Millán-Cayetano et al., 2020). Axillary dissection was done for the patient after a multidisciplinary team discussion as the PET scan did not show any other metastatic site and the disease was resectable.

Radiotherapy as the primary or definitive treatment is considered for sites where excision would result in cosmetic or functional deficit, irresectable tumours, and patients medically unfit for surgery (Mendenhall et al., 2009). In adjuvant setting radiotherapy is recommended for high risk features such as perineural involvement. Anne Han et al., literature review showed local central rate of $92-100 \%$ with mohs surgical excision combined with radiation compared to $38-100 \%$ with surgery alone (Han \& Ratner., 2007). Radiotherapy after nodal dissection for metastatic BCC has also been reported with good outcomes (Boswell et al., 2006) so in view the high risk features of our patient i.e., skin and lymphovascular invasion, poorly differentiated tumors, deep margin of clearance $0.3 \mathrm{~mm}$ radiotherapy was given in an adjuvant setting for better control of disease and to prevent recurrence. Other topical options that are available for low risk superficial BCC include topical imiquimod, cryotherapy, photodynamic therapies.

Systemic therapy for metastatic and advanced basal carcinoma after utilizing surgery and radiation is still in trials is FDA approved hedgehog inhibitor, vismodegib. In the ERIVANCE trial, after a median follow up of 21 months the response duration was 26.2 months ( locally advances) and 14.86 months (metastatic BCC) (Sekulic et al., 2017). Treatment associated serious side effects were observed to be $25-30 \%$. Other hedgehog inhibitor like sonidegip is FDA approved for locally advanced $\mathrm{BCC}$ recurring after surgery and radiation or when both are not possible but not for metastatic BCC (Migden et al., 2015). The use of these agent is limited by the development of resistance.

The prognosis of BCC is generally good as it is only locally aggressive. Once metastatic, the overall survival is 7 years for regional metastasis and 2 years for distant metastasis. Thus early recognition and prompt management is necessary to improve survival (Millán-Cayetano et al., 2020). Long term follow up should include a complete examination every 6 month for the first 2 years followed by a yearly exam. 


\section{Conclusion}

$\mathrm{BCC}$ is a local spreading disease, although metastasis is rare but complete physical examination is important to rule out regional and distant metastasis, especially in long standing, advanced with aggressive histologic features and recurring tumors.

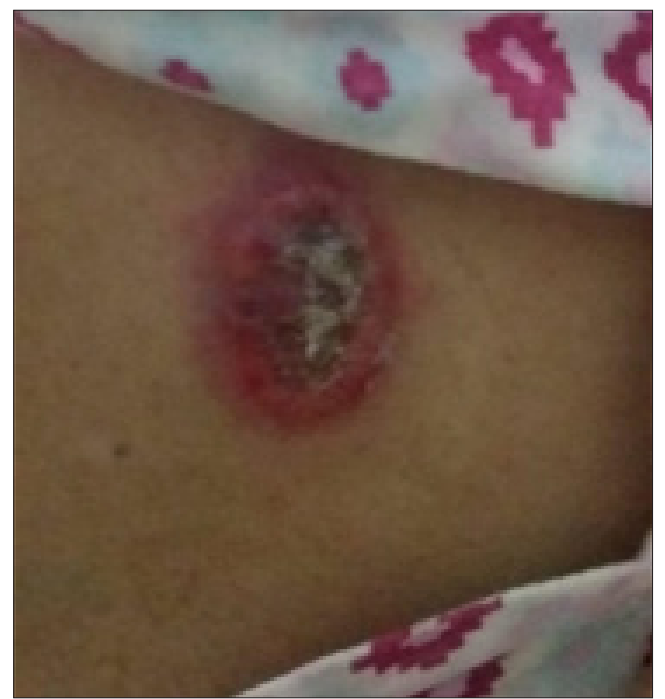

Figure 1: Basal cell carcinoma presenting as an ulcer at the left upper outer quadrant of breast

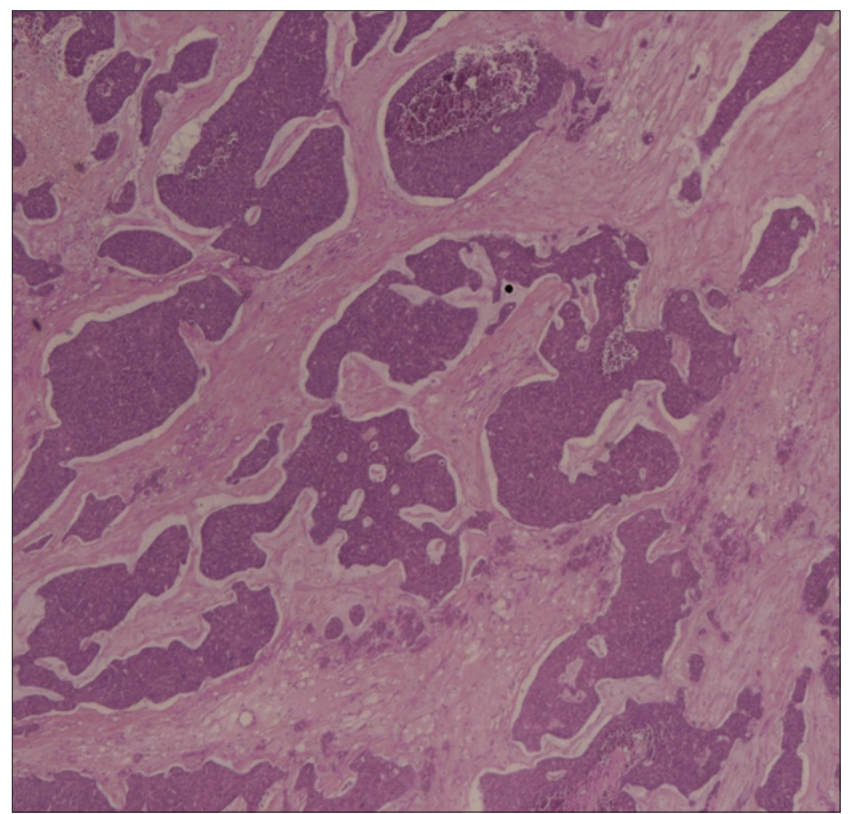

Nest of basaltic cells with moderately blue cytoplasm and dark ovoid nucleus with uniform chromatin. Palisading of cells at the edge of the cell nests with background of myxoid stroma. Lymphoid follicles seen at the periphery.

\section{Conflict of Interest}

The authors declare no conflict of interest and this is published to share knowledge only.

\section{References}

1. Peris, K., Fargnoli, M. C., Claus, G., Kaufmann, R., Bastholt, L., Seguin, N. B., Bataille, V., Marmol, V. D., Dummer, R., Harwood, C. A., Hauschild, A., Höller, Christoph., Haedersdal, Merete., Malvehy, Josep., Middleton, Mark. R., Morton, Colin. A., Nagore, E., Stratigos, A. J., Szeimies, R... Grob, J. J. (2019). Diagnosis and treatment of basal cell carcinoma: European consensus-based interdisciplinary guidelines. European journal of cancer (Oxford, England: 1990), 118:10-34. https://doi.org/10.1016/j.ejca.2019.06.003

2. Basset-Seguin, N., \& Herms, F. (2020). Update in the Management of Basal Cell Carcinoma. Acta dermatovenereologica, 100(11), adv00140. https://doi.org/10.2340/00015555-3495

3. Gellatly, M., Cruzval-O'Reilly, E., Mervak, J. E., \& Mervak, B. M. (2020). Metastatic basal cell carcinoma with atypical pattern of spread. Radiol Case Rep, 15(12), 2641-4. https://doi.org/10.1016/j.radcr.2020.09.054

4. Furlan, K., Reddy, V., Alabkaa, A., Rohra, P., Mir, F., \& Gattuso P. (2021). Metastatic head and neck cutaneous basal cell carcinomas: a retrospective observational study. Archives of Dermatological Research, 313(6), 439-43. https://doi.org/10.1007/s00403-020-02120-y

5. Mohan, S. V., \& Chang, A. L. S. (2014). Advanced Basal Cell Carcinoma: Epidemiology and Therapeutic Innovations. Current Dermatology Reports, 3(1), 40-45. https://dx.doi.org/10.1007\%2Fs13671-014-0069-y

6. Lernia, V. D., Ricci, C., Zalaudek, I., \& Argenziano, G. (2013). Metastasizing basal cell carcinoma. Cutis, 92(5), 244-6. Retrieved from https://pubmed.ncbi.nlm.nih. gov/24343210/

7. McCusker, M., Basset-Seguin, N., Dummer, R., Lewis, K., Schadendorf, D., Sekulic, A., Hou, J., Wang, L., Yue, H., \& Hauschild, Axel. (2014). Metastatic basal cell carcinoma: prognosis dependent on anatomic site and spread of disease. European journal of cancer (Oxford, England: 1990), 50(4), 774-83.

https://doi.org/10.1016/j.ejca.2013.12.013

8. Laga, A. C., Schaefer, I. M., Sholl, L. M., French, C. A., \& Hanna, J. (2019). Metastatic Basal Cell Carcinoma: Molecular Ancillary Testing and Reappraisal of Histopathology Within a Rare Entity. American journal of clinical pathology, 152(6), 706-17.

https://doi.org/10.1093/ajcp/aqz089

9. Didona, D., Paolino, G., \& Bottoni, U. (2018). Non Melanoma Skin Cancer Pathogenesis Overview. Biomedicines, 6(1),6. https://doi.org/10.3390/biomedicines6010006

10. Branson, S. V., McClintic, E., Ozgur, O., Esmaeli, B., \& Yeatts, R. P. (2017). Orbitofacial Metastatic Basal Cell Carcinoma: Report of 10 Cases. Ophthalmic plastic and reconstructive surgery, 33(3), 213-7. https://doi.org/10.1097/iop.0000000000000715

11. West, L., Fathi, R., Nijhawan, R., \& Srivastava, D. (2020). Metastatic basal cell carcinoma with evidence of intravascular invasion: A case report. SAGE open medical case reports, 8:2050313X19847782.

https://doi.org/10.1177/2050313x19847782 
12. Jankovic, I., Kovacevic, P., Visnjic, M., Jankovic, D., Binic, I., Jankovic, A., Binic, I., Jankovic, A., \& Ilic, I. (2011). Application of sentinel lymph node biopsy in cutaneous basosquamous carcinoma. Annals of dermatology, 23(Suppl 1), S123-S6.

https://dx.doi.org/10.5021\%2Fad.2011.23.S1.S123

13. Mochel, M. C., Liaquat, S., Moore, J. B., \& Hoang, M. P. (2021). Metastasizing basal cell carcinoma: A clinicopathologic and immunohistochemical study of 22 cases. Journal of Cutaneous Pathology, 48(3), 374-83. https://doi.org/10.1111/cup.13888

14. Gellatly, M., Cruzval-O'Reilly, E., Mervak, J. E., \& Mervak, B. M. (2020). Metastatic basal cell carcinoma with atypical pattern of spread. Radiol Case Rep, 15(12), 2641-4. https://doi.org/10.1016/j.radcr.2020.09.054

15. van Loo, E., Mosterd, K., Krekels, G. A. M., Roozeboom, M. H., Ostertag, J. U., Dirksen, C. D., Steijlen, P. M., Neumann, H. A. M., Nelemans, P. J., \& Kelleners-Smeets, N. W. J. (2014). Surgical excision versus Mohs\&\#x2019; micrographic surgery for basal cell carcinoma of the face: A randomised clinical trial with 10\&\#x2005; year followup. European Journal of Cancer, 50(17), 3011-20. https://doi.org/10.1016/j.ejca.2014.08.018

16. Mosterd, K., Krekels, G. A. M., Nieman, F. H. M., Ostertag, J. U., Essers, B. A. B., Dirksen, C. D., Steijlen, P. M., Vermeulen, A., Neumann, H., \& Kelleners-Smeets, N. W. J. (2008). Surgical excision versus Mohs' micrographic surgery for primary and recurrent basal-cell carcinoma of the face: a prospective randomised controlled trial with 5-years' follow-up. The Lancet Oncology, 9(12), 1149-56. https://doi.org/10.1016/s1470-2045(08)70260-2

17. Millán-Cayetano, J. F., Blázquez-Sánchez, N., FernándezCanedo, I., Repiso-Jiménez, J. B., Fúnez-Liébana, R., Bautista, M. D., \& Troya-Martin, M. D. (2020). Metastatic Basal Cell Carcinoma: Case Report and Review of the Literature. Indian journal of dermatology, 65(1), 614. Retrieved from https://www.e-ijd.org/printarticle. asp?issn $=0019-5154$; year $=2020$; volume $=65$; issue $=1$; spag $\mathrm{e}=61$; epage $=64$; aulast $=$ Millan-Cayetano

18. Mendenhall, W. M., Amdur, R. J., Hinerman, R. W., Cognetta, A. B., \& Mendenhall, N. P. (2009). Radiotherapy for cutaneous squamous and basal cell carcinomas of the head and neck. The Laryngoscope, 119(10), 1994-9. https://doi.org/10.1002/lary.20608

19. Han, A., \& Ratner, D. (2007). What is the role of adjuvant radiotherapy in the treatment of cutaneous squamous cell carcinoma with perineural invasion? Cancer, 109(6), 1053-9. https://doi.org/10.1002/cncr.22509

20. Boswell, J. S., Flam, M. S., Tashjian, D. N., \& Tschang, T. P. (2006). Basal cell carcinoma metastatic to cervical lymph nodes and lungs. Dermatology Online Journal, 12(6), 9. https://doi.org/10.5070/D38342r5bj

21. Sekulic, A., Migden, M. R., Basset-Seguin, N., Garbe, C., Gesierich, A., Lao, C. D., Miller, C., Mortier, L., Murrell, D. F., Hamid, O., Quevedo J. F., Hou, J., McKenna, E., Dimier, N., Williams, S., Schadendorf, D., \& Hauschild, A. (2017). Long-term safety and efficacy of vismodegib in patients with advanced basal cell carcinoma: final update of the pivotal ERIVANCE BCC study. BMC cancer, 17(1), 332. https://doi.org/10.1186/s12885-017-3286-5

22. Migden, M. R., Guminski, A., Gutzmer, R., Dirix, L., Lewis, K. D., Combemale, P., Herd, R. M., Kudchadkar, R., Trefzer, U., Gogov, S., Pallaud, C., Yi, T., Mone, M., Kaatz, M., Loquai, C., Stratigos, A. J., Schulze, H., Plummer, R., Chang, A. L. S., Cornélis, F... \& Dummer, R. (2015). Treatment with two different doses of sonidegib in patients with locally advanced or metastatic basal cell carcinoma (BOLT): a multicentre, randomised, doubleblind phase 2 trial. The Lancet Oncology, 16(6), 716-28. https://doi.org/10.1016/s1470-2045(15)70100-2
Copyright: C2021 Rufina Soomro. MICHELINI. This is an open-access article distributed under the terms of the Creative Commons Attribution License, which permits unrestricted use, distribution, and reproduction in anymedium, provided the original author and source are credited. 